\title{
Analisis hubungan kecemasan, aktivitas, dan motivasi berprestasi dengan hasil belajar matematika siswa
}

\author{
Hari Purnomo Susanto ${ }^{1}$
}

\begin{abstract}
Abstrak: Penelitian ini bertujuan untuk menganalisis hubungan antara kecemasan matematika, aktivitas, dan motivasi berprestasi dengan hasil belajar matematika siswa. Penelitian ini merupakan penelitian korelasional menggunakan metode analisis regresi. Data diambil dari 146 responden yang merupakan siswa MTsN 1 Pacitan kelas VIII. Variabel bebas pada penelitian ini yaitu kecemasan matematika $\left(X_{1}\right)$, aktivitas $\left(X_{2}\right)$ dan motivasi berprestasi $\left(X_{3}\right)$, sedangkan variabel terikatnya yaitu hasil belajar matematika siswa $(Y)$. Berdasarkan kombinasi dari 3 variabel bebas dan variabel terikat diperoleh 7 model regresi yang dianalisis. Analisis regresi dilakukan dengan menggunakan program SPSS. Hasil penelitian ini menunjukkan bahwa: 1) hubungan kecemasan matematika dengan hasil belajar matematika masuk dalam kategori rendah, 2) hubungan aktivitas siswa dengan hasil belajar matematika masuk dalam kategori rendah, 3) hubungan motivasi berprestasi dengan hasil belajar matematika masuk dalam kategori rendah, 4) hubungan kecemasan matematika dan aktivitas siswa dengan hasil belajar matematika masuk dalam kategori rendah, 5) hubungan kecemasan matematika dan motivasi berprestasi dengan hasil belajar matematika masuk dalam kategori rendah, 6) hubungan aktivitas dan motivasi berprestasi tidak dapat ditentukan karena koefisien regresi dari motivasi tidak dapat digunakan, dan 7) hubungan kecemasan matematika, aktivitas dan motivasi berprestasi masuk dalam kategori rendah. Hal ini terjadi karena adanya variasi nilai hasil belajar siswa pada setiap kategoris variabel-variabel bebasnya.
\end{abstract}

Kata kunci: Korelasi; Kecemasan Matematika; Aktivitas Balajar; Motivasi Berprestasi; Hasil Belajar Matematika

\begin{abstract}
This study aims to analyze the relationship between mathematics anxiety, learning activity, and achievement motivation towards the students' mathematics learning outcomes. This study is a correlational study using regression analysis method. Data were taken from 146 eight grade students of MTsN 1 Pacitan. Independent variables in this study are mathematics anxiety $\left(X_{1}\right)$, learning activity $\left(X_{2}\right)$, and achievement motivation $\left(X_{3}\right)$ while the dependent variable is students' mathematics learning outcomes $(Y)$. The combination of three independent variables and the dependent variable provides
\end{abstract}

\footnotetext{
${ }^{1}$ STKIP PGRI Pacitan, Indonesia, hazi328@yahoo.co.id
} 
seven regression models that had been analyzed. SPSS is used to conduct regression analysis. The results of this study show that: 1) the relationship between mathematics anxiety and the students' mathematics learning outcomes is in the low category; 2) The relationship between student's activity and learning outcomes of mathematics is in the low category; 3) the relationship between achievement motivation and learning outcomes is in the low category; 4) the relationship of students mathematics anxiety and activity with the students learning outcomes is in the low category; 5) the relationship of mathematics anxiety and achievement motivation with learning outcomes is in the low category; 6 ) the relationship of activity and achievement motivation could not be determined because the regression coefficient of motivation variable could not be used; and 7) the relationship of mathematics anxiety, activity and achievement motivation with student learning outcomes is in the low category. This occurs because of the variation of student learning outcomes in each category of the independent variables.

Keywords: Correlation; Math Anxiety; Learning Activity; Achievement Motivation; Mathematics Learning Outcomes

\section{A. Pendahuluan}

Hasil belajar siswa merupakan pengetahuan, keterampilan dan kemampuan yang dimiliki siswa, sebagai hasil pembelajaran yang di tempuh (Werquin, 2010). Jika dikaitkan dengan pembelajaran matematika maka hasil belajar matematika merupakan pengetahuan, keterampilan dan kemampuan matematika siswa, sebagai hasil dari pembelajaran yang ditempuh siswa. Hasil belajar matematika sering disajikan sebagai bentuk representasi kognitif matematis siswa berupa angka atau huruf.

Hasil belajar matematika siswa diperoleh setelah menempuh pembelajaran matematika. Hasil belajar dapat diukur dari proses dan hasil-hasil tes yang dilakukan oleh siswa. Selama proses belajar matematika, banyak sekali faktor-faktor yang dapat berpengaruh sehingga berdampak pada hasil belajar yang diperoleh siswa. Djamarah (2008) berpendapat bahwa faktor-faktor tersebut dapat muncul dari dalam diri siswa (internal) atau luar siswa (eksternal). Faktor internal meliputi intelegensi, motivasi, kebiasaan, kecemasan, aktivitas, minat, dan sebagainya. Sedangkan faktor eksternal meliputi lingkungan keluarga, lingkungan masyarakat, lingkungan sekolah, keadaan sosial, dan sebagainya. Dari berbagai faktor yang mempengaruhi proses siswa dalam 
belajar, dalam artikel ini hanya dibatasi pada beberapa faktor saja yaitu kecemasan, Aktivitas belajar, dan motivasi berprestasi.

Kecemasan merupakan sebuah kondisi psikologi seseorang yang penuh dengan perasaan tegang, khawatir dan takut terhadap sesuatu yang akan terjadi atau yang dihadapinya (Barker, et.al. 2007; Singgih, 2008; Az Zahrani, 2005; \& Rahman, 2004). Kecemasan menjadi salah satu faktor yang mendominasi dalam pembelajaran. Kecemasan dalam belajar sangat berpengaruh terhdap proses belajar siswa, baik di sekolah, di lingkungan keluarga maupun di pergaulan. Kecemasan dalam proses belajar di sekolah menjadi hambatan yang serius ketika mempelajari mata pelajaran tertentu. Mata pelajaran yang sering membuat siswa cemas yaitu pelajaran Matematika.

Kecemasan matematika merupakan sebuah kondisi yang takut dan khawatir terhadap pembelajaran matematika. Kecemasan matematika muncul sebagai respon dari apa yang sedang dihadapi dalam pembelajaran matematika. Kecemasan matematika dapat muncul karena dipicu oleh kemampuan siswa yang kurang dalam matematika, karakter guru matematika, model pembelajaran yang digunakan oleh guru, kesulitan matematika, dan tidak percaya diri. Richardson dan Suinn (1972) menyatakan bahwa kecemasan dalam matematika berpengaruh terhadap cara siswa dalam menyelesaikan masalah matematika kontekstual dan akademik. Senada dengan pendapat tersebut, Ashcraft (2002) berpendapat bahwa kecemasan matematika sebagai perasaan ketegangan, cemas atau ketakutan yang dapat menganggu kinerja dalam belajar matematika. Selain itu, Blazer (2011) dan Ashcraft (2002) dalam penelitiannya menyatakan bahwa kecemasan dapat mengganggu kinerja siswa yang berdampak pada berkurangnya kinerja ingatan dan tidak dapat menggunakan informasi yang pernah diperoleh untuk menyelesaikan tes yang sedang di hadapi.

Kecemasan matematika pada siswa dapat dilihat ketika siswa mengeluh, merasa tidak nyaman, dan tidak tenang ketika belajar matematika di dalam kelas. Kondisi ini sering mewarnai proses pembelajaran matematika sehingga dapat berpengaruh terhadap hasil yang akan diperoleh siswa. Dari beberapa penelitian (Anggreini, 2010; Anita, 2014; Leonard \& Supardi, 2010) menunjukkan bahwa semakin tinggi tingkat kecemasan yang dialami oleh siswa maka semakin kecil hasil yang diperoleh oleh siswa dan berlaku sebaliknya. 
Aktivitas belajar juga menentukan hasil belajar yang diperoleh oleh siswa. Sejalan dengan Ardhi (2007) dalam penelitiannya menyimpulkan bahwa aktivitas belajar memiliki pengaruh yang kuat terhadap hasil belajar. Aktivitas belajar merupakan sebuah kondisi di mana siswa sangat aktif dalam mengolah dan merespon informasi yang disampaikan oleh guru (Hamalik, 2008). Siswa yang aktif dalam kelas dapat dilihat dari bagaimana anak tersebut mendengarkan pendapat orang lain, berdiskusi, mengerjakan laporan tugas, membantu teman yang kesulitan dan lain-lain.

Aktivitas belajar matematika sangat menentukan hasil yang akan diperoleh siswa, sehingga sangat perlu adanya pengukuran yang berkaitan dengan aktifitas belajar matematika. Pengukuran dapat dilakukan dengan dua cara yaitu pertama, pengukuran melalui observasi dan pengamatan oleh guru. Aktivitas siswa dalam belajar matematika kurang dapat di amati jika guru menggunakan metode pembelajaran langsung dan ceramah. Model pembelajaran kooperatif merupakan salah satu metode pembelajaran yang dapat digunakan untuk melihat aktivitas belajar siswa belajar di dalam kelas. Jadi untuk setiap bahasan guru harus paham seberapa sulit materi yang di sampaikan sekaligus menentukan model yang cocok, sehingga guru dapat mengamati aktivitas belajar siswa dalam kelompok di kelas, bahkan dalam hal ini guru dapat membentuk aktivitas siswa dalam belajar.

Motivasi berprestasi merupakan salah satu faktor yang dapat mempengaruhi hasil belajar selain aktivitas dan kecemasan matematika. Motivasi berprestasi merupakan upaya siswa dalam menguasai tugas, mencapai keunggulan, mengatasi hambatan, memilikii performa yang lebih baik dan sangat bangga dengan kemampuannya (Weinberg \& Gould, 2011; Rao, 2003). Rao (2003) juga menyatakan bahwa motivasi berprestasi yang dimiliki oleh seseorang dapat digunakan untuk menyelesaikan tugas-tugas tertentu yang berstandar unggulan dan memperoleh hasil yang diinginkan. Motivasi berprestasi dalam diri siswa akan menumbuhkan jiwa kompetisi yang sehat, akan menumbuhkan individu-individu yang bertanggung jawab dan dengan motivasi berprestasi yang tinggi juga akan membentuk individu menjadi pribadi yang kreatif. Untuk itu motivasi memegang peranan penting dalam memberikan gairah, semangat dan rasa senang dalam belajar sehingga 
yang memiliki motivasi tinggi mempunyai energi yang banyak untuk melaksanakan kegiatan belajar (Uno, 2012).

Motivasi berprestasi yang dimiliki seorang siswa dapat ditingkatkan untuk memperoleh hasli yang sesuai dengan keinginan. Guru matematika memiliki peranan penting dalam meningkatkan motivasi berprestasi yang dimiliki siswa ketika belajar matematika. Meningkatnya motivasi berprestasi akan berpengaruh terhadap meningkatnya hasil belajar ssiswa. Penelitian yang dilakukan Wijayanti (2014) yang berkaitan dengan motivasi berprestasi dengan hasil belajar menyimpulkan bahwa terdapat pengaruh motivasi berprestasi terhadap hasil belajar siswa.

Berdasarkan penjelasan di atas, maka siswa yang tidak memiliki motivasi dalam belajar akan berakibat buruk terhadap prestasi akademiknya. Oleh sebab itu, motivasi berprestasi sangat dibutuhkan dalam proses belajar, karena jika segala sesuatunya itu dipaksakan maka akan sangat berpengaruh terhadap hasil yang diperoleh. Hal ini merupakan pertanda bahwa jika sesuatu yang dikerjakan itu tidak dengan adanya dorongan dari dalam maupun luar diri siswa, maka akan membuat siswa tidak dapat mencapai tujuannnya.

Beberapa faktor di atas yaitu kecemasan matematika, aktivitas belajar, dan motivasi berprestasi sama-sama memiliki pengaruh terhadap hasil belajar yang diperoleh siswa dalam proses belajar. Banyak penelitian hanya mengamati hubungan dan pengaruh ketiga faktor tersebut secara terpisah. Misalnya Puteh \& Khalin (2016), Anggreini (2010), dan Ramirez et al (2016) yang meneliti hubungankecemasan dengan hasil belajar saja. Sahidin dan Jamil (2013), dan Chaerani (2011) yang meneliti hubungan motivasi berprestasi dan hasil belajar. Ferchilia, Risyak, dan Rohan Cut (2004) yang meneliti tentang hubungan motivasi dan aktivitas dengan prestasi. Selain itu hanya dilihat berpengaruh atau tidaknya, sehingga tidak dapat diketahui seberapa besar pengaruh setiap faktor terhadap hasil belajar. Sehingga tidak dapat ditentukan secara rinci faktor mana yang harus ditingkatkan terlebih dahulu untuk menghadapi pembelajaran pada pembahasan selanjutnya. Berdasarkan penjelasan sebelumnya, pada artikel ini akan dilakukan analisis hubungan dan besar pengaruh dari ketiga faktor di atas dengan hasil belajar matematika, baik secara sendirisendiri maupun bersama-sama. 


\section{B. Metode Penelitian}

Penelitian ini merupakan penelitian korelasi (Correlational Research). Penelitian korelasi dilakukan untuk menyelidiki ada tidaknya hubungan yang terjadi pada variabel-variabel penelitian (Arikunto, 2010). Untuk melihat hubungan antar variabel bebas dan terikat menggunakan analisis regresi liniear sederhana atau berganda.

Analisis regresi harus memenuhi beberapa uji asumsi klasik (Berry \& Feldman, 1985; \& Budiyono, 2009). Uji asumsi tersebut sebagai syarat agar analisis yang dilakukan dapat digunakan. Uji-uji tersebut yaitu, 1) normalitas residual harus berdistribusi normal, 2) variabel terikat harus berdistribusi normal, 3) pada regresi berganda tidak terjadi multikolinieritas, 4) tidak terdapat heteroskedastisitas, 5) tidak terjadi autokoelasi antara data dalam satu variabel, tetapi uji autokoelasi tidak di uji pada artikel ini karena tipe data dari setiap variabel pada penelitian ini tidak bertipe time series yaitu data seorang responden satu tidak akan mempengaruhi responden yang lain. Perhitungan analisis regresi dan uji asumsi klasik pada tulisan dilakukan dengan menggunakan SPSS 16.

Penelitian ini dilakukan di MTs Negeri Pacitan, Kecamatan Pacitan, Kabupaten Pacitan. Adapun populasi dalam penelitian ini yaitu seluruh siswa-siswa kelas VIII MTs Negeri Pacitan tahun pelajaran 2015/2016 sebanyak 2016 siswa. Sampel penelitiannya dihitung dengan Nomogram Herry King dengan taraf kesalahan 5\% dan dari Nomogram Herry King diperoleh persentase sampel sebesar $54 \%$. Jadi banyak sampel minimal yaitu yang dapat digunakan $n=5 \% \times 95 \% \times 216=139,38=139$ siswa. dari 6 kelas di gunakan 4 kelas dengan banyak siswa 146, sehingga sampel yang digunakan 146 siswa.

Pada penelitian ini ada tiga variabel bebas dan satu variabel terikat. Variabel-variabel bebas tersebut diantaranya yaitu kecemasan matematika $\left(X_{1}\right)$, aktivitas $\left(X_{2}\right)$, dan motivasi berprestasi $\left(X_{3}\right)$. Sedangkan variabel terikatnya yaitu hasil belajar matematika. Data dari setiap variabel bebas diambil menggunakan angket. Sedangkan untuk data hasil belajar diminta langsung dari guru matematika.

Sebelum digunakan untuk mengambil data, angket diujicobakan kepada 33 siswa yang merupakan kelas VIIID di MTs N Pacitan. Angket kecemasan sebanyak 43 butir pernyataan, setelah diuji coba terdapat 8 tidak valid. Selanjutnya angket aktivitas belajar sebanyak 30 butir, setalah 
diuji coba semua item pernyataan valid. Sedangkan pada angket motivasi berprestasi terdapat 35 butir pernyataan, setelah diuji coba terdapat 5 tidak valid. Berdasarkan saran reviewer, butir-butir pernyataan yang tidak valid dapat digunakan untuk mengambil data setelah diperbaiki.

Menurut Arikunto (2010) Kekuatan hubungan antar variabel bebas terhadap variabel terikat dapat dilihat pada out put SPSS 16.0 tabel summary nilai $\mathrm{R}$ lalu disesuaikan dengan tabel interpretasi nilai $\mathrm{R}$.

Tabel 1. Tabel Interpretasi Nilai R

\begin{tabular}{|l|c|}
\hline \multicolumn{1}{|c|}{ Besar Nilai $R$} & Interpretasi \\
\hline Antara 0.800 sampai dengan 1.00 & Tinggi \\
\hline Antara 0.600 sampai dengan 0.800 & Cukup \\
\hline Antara 0.400 sampai dengan 0.600 & Sedang \\
\hline Antara 0.200 sampai dengan 0.400 & Rendah \\
\hline Antara 0.000 sampai dengan 0.200 & Sangat Rendah \\
\hline
\end{tabular}

\section{Hasil dan Pembahasan}

Data tentang kecemasan matematika $\left(\mathrm{X}_{1}\right)$, aktivitas Belajar $\left(\mathrm{X}_{2}\right)$, dan motivasi berprestasi $\left(X_{3}\right)$ diperoleh dari pengambilan secara langsung dengan menggunakan angket. Sedangkan data tentang hasil belajar di minta secara langsung dari guru. Selanjutnya analisis data pada artikel ini dilakukan dengan menentukan hubungan setiap variabel bebas dengan variabel terikat diperoleh 3 model regresi. Kombinasi dari setiap variabel bebas untuk menentukan hasil belajar diperoleh 4 model regresi, sehingga pada artikel ini diperoleh 7 model regresi.

Tabel 2. Model-model regresi hasil output SPSS

\begin{tabular}{|c|l|c|}
\hline Model & \multicolumn{1}{|c|}{ Bentuk umum regresinya } & $\begin{array}{c}\text { Signifikansi } \\
\text { (sign.) }\end{array}$ \\
\hline 1 & $Y=96,926-0,313 X_{1}$ & $0,013^{\mathrm{a}}$ \\
\hline 2 & $Y=48,671+0,321 X_{2}$ & $0,003^{\mathrm{a}}$ \\
\hline 3 & $Y=59,002+0,262 X_{3}$ & $0,043^{\mathrm{a}}$ \\
\hline 4 & $Y=72,595-0,346 X_{1}+0,346 X_{2}$ & $0,000^{\mathrm{a}}$ \\
\hline 5 & $Y=82,558-0,332 X_{1}+0,285 X_{3}$ & $0,004^{\mathrm{a}}$ \\
\hline 6 & $Y=38,561+0,296 X_{2}+0,217 X_{3}$ & $0,003^{\mathrm{a}}$ \\
\hline 7 & $Y=62,287-0,353 X_{1}+0,308 X_{2}+0,250 X_{3}$ & $0,000^{\mathrm{a}}$ \\
\hline
\end{tabular}


Tabel 3. Model Summary ${ }^{b}$

\begin{tabular}{|c|c|c|c|c|}
\hline Model & $R$ & $R$ Square & $\begin{array}{c}\text { Adjusted } R \\
\text { Square }\end{array}$ & $\begin{array}{c}\text { Std. Error of the } \\
\text { Estimate }\end{array}$ \\
\hline 1 & $0,206^{\mathrm{a}}$ & 0,042 & 0,036 & 6,74201 \\
\hline 2 & $0,240^{\mathrm{a}}$ & 0,058 & 0,051 & 6,68721 \\
\hline 3 & $0,168^{\mathrm{a}}$ & 0,028 & 0,021 & 6,79127 \\
\hline 4 & $0,330^{\mathrm{a}}$ & 0,109 & 0,097 & 6,52535 \\
\hline 5 & $0,275^{\mathrm{a}}$ & 0,076 & 0,063 & 6,64696 \\
\hline 6 & $0,277^{\mathrm{a}}$ & 0,077 & 0,064 & 6,64266 \\
\hline 7 & $0,363^{\mathrm{a}}$ & 0,132 & 0,114 & 6,46391 \\
\hline
\end{tabular}

Berdasarkan hasil analisis di atas berikut diberikan penjelasan dan pembahasan dari masing-masing model. Selain itu, hasil dalam penelitian ini dibandingkan dengan beberapa penelitian yang memang sudah ada.

\section{Model 1 (Kecemasan dengan hasil belajar)}

Hubungan kecemasan matematika dan hasil belajar siswa dapat dilihat dari persamaan model 1 . Pada model tersebut setiap terjadi perubahan satu satuan pada $X_{1}$ maka menurunkan nilai hasil belajar sebesar $-0,313$. Tanda Negatif pada koefisen $X_{1}$ menunjukkan bahwa kecemasan matematika memiliki hubungan yang negatif dengan hasil belajar. Karena memiliki hubungan yang negatif maka semakin tinggi kecemasan matematika siswa, maka semakin rendah hasil belajar yang diperoleh siswa. Model 1 memiiki koefisien korelasi $R=0,206$ yang menyatakan bahwa kekuatan hubungan kecemasan matematika dengan hasil belajar tergolong rendah. Nilai koefeisien determinasi model $1, R^{2}=$ 0,042 yang berarti bahwa kecemasan matematika dapat mempengaruhi hasil belajar sebesar 4,2\%, dan sekitar 95,8\% dipengaruhi oleh faktor lain.

Sejalan dengan hasil tersebut (Leonard, 2009; Anggreini, 2010; Blazer, 2011) menyatakan bahwa kecemasan matematika memiliki hubungan negatif dengan hasil belajar. Hasil penelitian Blazer (2011) menyatakan bahwa matematika memiliki hubungan sangat kuat dengan hasil belajar matematika. Sebaliknya, Anggreini (2010) memberikan gambaran yang sama dengan hasil penelitian ini yaitu menunjukkan bahwa kecemasan matematika memiliki hubungan yang rendah dengan hasil belajar. 


\section{Model 2 (Aktivitas dengan hasil belajar)}

Hubungan aktivitas dan hasil belajar siswa dapat dilihat dari model 2. Pada model tersebut setiap terjadi perubahan satu-satuan pada $X_{2}$ maka menaikan nilai hasil belajar sebesar 0,321. Tanda positif pada koefisen $X_{2}$ menunjukkan bahwa aktivitas belajar siswa memiliki hubungan yang positif dengan hasil belajar siswa. Karena memiliki hubungan yang positif maka semakin tinggi tingkat Aktivitas siswa, maka semakin tinggi pula hasil belajar yang diperoleh siswa. sesuai dengan pendapat Dyahayu (2015) yang menyatakan bahwa dengan Aktivitas siswa dalam proses pembelajaran maka akan berdampak positif terhadap hasil belajar yang diperoleh siswa. Model 2 memiiki Koefisien korelasi $R=0,206$ yang menyatakan bahwa kekuatan hubungan Aktivitas dengan hasil belajar tergolong rendah. Nilai koefeisien determinasi model 2 yaitu $R^{2}=$ 0,058 yang berarti bahwa Aktivitas dapat mempengaruhi hasil belajar sebesar 5,8\%, dan sekitar 93,2\% dipengaruhi oleh faktor lain. Sejalan dengan hasil tersebut Simanjutak (2013) dalam penelitiannya menyimpulkan bahwa aktivitas belajar memilki hubungan yang positif dan sedang dengan hasil belajar.

\section{Model 3 (Motivasi berprestasi dengan hasil belajar)}

Hubungan antara motivasi berprestasi dengan hasil belajar dapat dilihat dari model 3. Pada model tersebut setiap terjadi perubahan satu satuan pada $X_{3}$ maka menaikan nilai hasil belajar sebesar 0,262 . Tanda positif pada koefisen $X_{3}$ menunjukkan bahwa motivasi berprestasi memiliki hubungan yang positif dengan $Y$ dengan hasil belajar. Hubungan yang positif menunjukkan bahwa semakin tinggi tingkat motivasi berprestasi siswa, maka semakin tinggi pula hasil belajar didapat siswa. hasil tersebut sesuai dengan teori Albert (2015) yang menyatakan bahwa semakin kuat dorongan sisiwa dalam belajar untuk berprestasi maka semakin tinggi hasil belajar yang diperoleh siswa. Model 3 memiiki Koefisien korelasi $R=0,168$ yang menyatakan bahwa kekuatan hubungan motivasi berprestasi dengan hasil belajar tergolong rendah. Nilai koefeisien determinasi model 3 yaitu $R^{2}=0,028$ yang berarti bahwa motivasi berprestasi dapat mempengaruhi hasil belajar sebesar $2,8 \%$, dan sekitar $97,2 \%$ dipengaruhi oleh faktor lain. Selanjutnya Sahidin \& Jamil 
(2013) menyimpulkan bahwa motivasi berprestasi memeiliki pengaruh yang positif dengan hasil belajar.

Hasil ini sesuai dengan hasil penelitian yang menyimpulkan bahwa motivasi berpretasi memiliki hubungan yang kuat dan positif (Sappaile, 2007; Chaerani, 2011; Anggraini, 2014). Ernawati (2012) menyimpulkan bahwa motivasi berprestasi dengan hasil belajar memiliki hubungan yang positif dan sedang. Sedangkan dalam penelitian ini motivasi berprestasi memiliki hubungan yang positif dan rendah.

\section{Model 4 (Kecemasan dan Aktivitas dengan Hasil belajar)}

Hubungan kecemasan matematika dan aktivitas belajar siswa secara bersama-sama dengan hasil belajar siswa dapat dilihat dari model 4. Pada persamaan tersebut setiap terjadi perubahan satu satuan pada $X_{1}$ dan $X_{2}$ maka tidak mebuat nilai hasil belajar berubah atau konstan. Model 4 memiliki Koefisien korelasi $R=0,330$ yang menyatakan bahwa kekuatan hubungan kecemasan matematika dan Aktivitas secara bersama-sama dengan hasil belajar tergolong rendah. Nilai koefeisien determinasi model $4, R^{2}=0,109$ yang berarti bahwa kecemasan mateamtika dan Aktivitas secara bersama-sama dapat mempengaruhi hasil belajar sebesar $10,9 \%$, dan sekitar $89,1 \%$ dipengaruhi oleh faktor lain.

\section{Model 5 (Kecemasan dan motivasi berprestasi dengan hasil belajar)}

Hubungan kecemasan matematika dan motivasi berprestasi secara bersama-sama dengan hasil belajar matematika dapat dilihat dari model 5. Pada model tersebut setiap terjadi perubahan satu satuan pada $X_{1}$ dan $X_{3}$ secara bersama-sama tidak mebuat nilai hasil belajar berubah atau konstan. Sejalan dengan hasil penelitian Solikah (2012) menyimpulkan bahwa kecemasan dan motivasi berprestasi secara bersama-sama mempengaruhi hasil belajar. Model 5 memiliki Koefisien korelasi $R=0,275$ yang menyatakan bahwa kekuatan hubungan kecemasan matematika dan motivasi berprestasi secara bersama-sama dengan hasil belajar tergolong rendah. Nilai koefeisien determinasi model $5, R^{2}=0,076$ yang berarti bahwa kecemasan matemtika dan motivasi secara bersama-sama dapat mempengaruhi hasil belajar sebesar 7,6\%, dan sekitar $92,4 \%$ dipengaruhi oleh faktor lain. 


\section{Model 6 (Aktivitas dan motivasi berprestasi dengan hasil belajar)}

Hubungan antara aktivitas belajar dan motivasi berprestasi secara bersama-sama dengan hasil belajar dapat dilihat dari model 6. Pada persamaan tersebut menunjukkan bahwa varibel motivasi dan Aktivitas tidak dapat digunakan secara bersama-sama untuk menentukan nilai dari hasil belajar siswa. Hal ini disebabkan koefisien dari $X_{3}$ sesuai uji keberartian koefisien tidak dapat dapat digunakan. sehingga model 6 tidak jauh berbeda dengan model 2 walaupun terdapat perbedaan konstanta dan koefisien dari $X_{2}$ pada keduanya. Sejalan dengan hasil penelitian Ferchilia, Risyak \& Rohan (2004) menyimpulkan bahwa terdapat hubungan kendatipun tidak nyata antara aktivitas dan motivasi berprestasi secara bersama-sama dengan hasil belajar.

\section{Model 7 (Kecemasan, aktivitas, dan motivasi berprestasi dengan hasil belajar)}

Hubungan antara kecemasan matematika, aktivitas, dan motivasi berprestasi secara bersama-sama dengan hasil belajar matematika dapat dilihat dari model 7. Pada persamaan tersebut setiap terjadi perubahan satu satuan pada $X_{1}, X_{2}$ dan $X_{3}$ maka akan menaikan nilai hasil belajar sebesar 2,05. Model 7 memiliki Koefisien korelasi $R=0,363$ yang menyatakan bahwa kekuatan hubungan kecemasan matematika dan motivasi secara bersama-sama dengan hasil belajar tergolong rendah. Nilai koefeisien determinasi model $7 R^{2}=0,132$ yang berarti bahwa kecemasan matemtika dan motivasi berprestasi secara bersama-sama dapat mempengaruhi hasil belajar sebesar 13,2\%, dan sekitar $86,8 \%$ dipengaruhi oleh faktor lain.

\section{Simpulan}

Berdasarkan hasil analisis hasil dan pembahasan dapat disimpulkan bahwa: 1) hubungan kecemasan matematika dengan hasil belajar matematika masuk dalam kategori rendah, 2) hubungan aktivitas siswa dengan hasil belajar matematika masuk dalam kategori rendah, 3) hubungan motivasi berprestasi dengan hasil belajar matematika masuk dalam kategori rendah, 4) hubungan kecemasan matematika dan aktivitas siswa dengan hasil belajar matematika masuk dalam kategori rendah, 5) hubungan kecemasan matematika dan motivasi berprestasi dengan hasil belajar matematika masuk 
dalam kategori rendah, 6) hubungan aktivitas dan motivasi berprestasi tidak dapat ditentukan karena koefisien regresi dari motivasi tidak dapat digunakan, dan 7) hubungan kecemasan matematika, Aktivitas dan motivasi berprestasi masuk dalam kategori rendah

Hubungan yang rendah tersebut dikarenakan adanya variasi hasil belajar matematika pada setiap kategorisasi variabel-variabel bebasnya. Sebagai contoh, dari 23 siswa yang memiliki kecemasan tinggi ternyata masi 3 siswa memiliki hasil belajar yang tinggi, 11 sedang dan 9 rendah. Secara matematis, jika dikaitkan dengan hasil yang menyatakan bahwa kecemasan memiliki hubungan yang negatif dengan hasil belajar, maka terdapat 3 siswa yang tidak memenuhi pernyataan tersebut dan 11 siswa yang agak memenuhi pernyataan tersebut. Untuk lebih jelasnya harus dilakukan penelitian lanjut berkaitan dengan kasus ini, karena pengaruh interaksi setiap kategorisasi variabel bebas tidak dapat dilihat secara langsung.

\section{Daftar Pustaka}

Angraini, R.D. (2014, November). Hubungan motivasi berprestasi dengan hasil belajar siswa pada pembelajaran matematika kelas V/A SDN No 13/1 Muara Bulian (Artikel). Diakses di http://www.ecampus.fkip.unja.ac.id/eskripsi/data/pdf/jurnalmhs/artikel/A1D110134.pdf

Anggreini, T. (2010). Hubungan antara kecemasan dalam menghadapi mata pelajaran matematika dengan prestasi akademik matematika pada remaja (Artikel skripsi). Diakses di http://www.gunadarma.ac.id/library Larticles/graduate/psychology/2010/Artikel 10505235.pdf

Anita, I.W. (2014). Pengaruh kecemasan matematika (mathematics anxiety) terhadap kemampuan koneksi matematis siswa SMP. Jurnal IImiah Program Studi Matematika, 3/1, 125-132. Bandung: STKIP Siliwangi Bandung.

Ardhi, E. R. (2007). Pengaruh aktivitas belajar dan minat siswa dalam pembelajaran student teams achievement division (STAD) terhadap hasil belajar matematika siswa kelas V semester II dalam pokok bahasan pecahan di SD Negeri Kalirejo tahun pelajaran 2006/2007 (Artikel). Diakses di http://lib.unnes.ac.id/647/

Arikunto, S. (2010). Prosedur penelitian. Jakarta: Rineka Cipta.

Ashcraft, M.H. (2002). Math Anxiety: Personal, Educational, and Cognitive Consequences. Current Directions in Psychological Science, 11, 181-185.

Az-zahrani, M.B.S. (2005). Konseling terapi. Jakarta: Gema Insani Press. 
Barker, Ray., Gledil, A., Lydon, Cris., Mulligan, Cris \& Saffery, G. (2007). BTEC National Sport, Book 1. $2^{\text {nd }}$ Edition. England : Heinemman

Berry, W.D. \& Feldman, S. (1985). Multiple regression in practice. Series : quantitative applications in the social sciences. Newbury Park, CA : Sage.

Blazer, C. (2011, September). Strategies for reducing math anxiety (artikel). Diakses di http://files.eric.ed.gov/fulltext/ED536509.pdf

Budiyono. (2009). Statistika untuk penelitian.edisi ke-2. Solo: UNS press

Chaerani, N. (2011). Hubungan motivasi berprestasi dengan hasil belajar matematika siswa SMP Global Islamic School Jakarta (Master thesis). Diakses di http://repository.uinjkt.ac.id/dspace/ bitstream/123456789 /5215/1/NOVITA\%20CHAERANI-FITK

Djamarah, S.B. (2008). Psikologi belajar. Jakarta: Rineka Cipta.

Ernawati. (2012. Januari). Hubungan antara motivasi berprestasi dan kemampuan numerik dengan prestasi belajar matematika di SMP Muhammadiyah 06 Dau Malang (Artikel). Diakses di https://www.researchgate.net/publication/50812996 HUBUNGAN ANTA RA MOTIVASI BERPRESTASI DAN KEMAMPUAN NUMERIK DENGANPRE STASI BELAJAR MATEMATIKA DI SMP MUHAMMADIYAH 06 DAU MAL ANG

Ferchilia, Y., Risyak, H. \& Rohan Cut.(2004). Hubungan motivasi belajar dan aktivitas belajar dengan prestasi belajar (Artikel). Diakses di http://www.ejurnal.com/2015/10/hubungan-motivasi-belajar-dan-aktivitas.html

Hamalik. (2008). Proses belajar mengajar. Jakarta : Bumi Aksara.

Leonard \& Supardi U.S. (2010). Pengaruh konsep diri, sikap siswa pada matematika, dan kecemasan siswa terhadap hasil belajar matematika. Jurnal Cakrawala Pendidikan, 1/3, 341-352. Diakses di http://journal.uny.ac.id/index.php/cp/article/view/362/pdf

Puteh, M. \& Khalin, S. Z. (2016). Mathematics anxiety and its relationship with the achievement of secondary students in malaysia. 6/2. 119-122. DOI: 10.7763/IJSSH.2016.V6.630. diakses di www.ijssh.org/vol6/630-P018.pdf

Rahman, S. (2004). Clinical psycology a modular course, anxiety. $2^{\text {nd }}$ edition. East Sussex: Psychology Press Ltd.

Rao, M.S. (2003). Achievement motivation and achievement in mathematics. India: Discovery Publising House

Ramirez, G., Chang, H., Erin, A.M., Levin,S.C \& Beilock, S.L. (2016). On the relationship between math anxiety and math achievement in early elementary school: the role of problem solving strategies. Journal of Experimental Child Psychology. 141, 83-100. Diakses di http://www.elsevier.com/locate/jecp

Richardson, F. C., \& Suinn, R. M. (1972). The Mathematics Anxiety Rating Scale: Psychometric data. Journal of Counseling psychology, 19(6), 551554. doi: $10.1037 / \mathrm{h} 0033456$ 
Sahidin, L. \& Jamil, D. (2013). Pengaruh motivasi berprestasi dan persepsi siswa tentang cara guru mengajar terhadap hasil belajar matematika. Jurnal Pendidikan Matematika, 4/2, 211-222. Diakses di http://118.97.35.230/lemlit/jtt/243.pdf

Sappaile, B.I. (2007). Hubungan kemampuan penalaran dalam matematika dan motivasi berprestasi terhadap prestasi belajar matematika. Jurnal Pendidikan dan Kebudayaan, 13/69, 985-1003. Diakses di http://jurnaldikbud.kemdikbud.go.id/index.php/jpnk/issue/view/29

Simanjuntak, T.M.D.(2013). Hubungan pengelolaan kelas dan aktivitas belajar siswa terhadap hasil belajar matematika menggunakan model pembelajaran kooperatif tipe STAD siswa kelas X SMA Swasta Mulia Medan tahun ajaran 2012/2013 (Artikel). Diakses di http://digilib.unimed.ac.id/10628/

Solikah, M. (2012). Pengaruh kecemasan siswa pada matematika dan motivasi belajar terhadap prestasi belajar matematika (Artikel). Diakses di http://ejournal.unesa.ac.id/index.php/mathedunesa/article/view/251

Singgih, D.G. (2008). Psikologi perawatan. Jakarta: Gunung Mulia Uno, H. (2012). Teori motivasi dan pengukurannya. Jakarta: Bumi Aksara.

Weinberg, R.S \& Gould, D. (2011). Foundations of sport and exercise psychology, 5Ed. USA: Human Kinetics

Werquin, P. (2010). Recognising non-formal and informal learning outcomes, policies and practice. OECD.

Wijayanti, F.R. (2014). Pengaruh konsep diri dan motivasi berprestasi terhadap hasil belajar matematika siswa kelas VIII SMP Negeri 1 Tulakan (Master thesis). Dapat diakses diperpustakaan STKIP PGRI Pacitan. 